\title{
Teaching Techniques Applied in Speaking Classes: Lecturers' Voice of What and Why
}

\author{
Rahmah Isnaniah $^{1 *}$, Nanik Mariani $^{2}$, Jumariati $^{3}$ \\ 1,2,3, Universitas Lambung Mangkurat \\ ${ }^{* *}$ Corresponding author.Email: isnaniahrahmah@gmail.com
}

\begin{abstract}
This research aimed to investigate the teaching techniques used and mostly used by the lecturers in Basic Speaking classes. Furthermore, the factors underlie their choice in using certain techniques more often than other techniques. It used descriptive qualitative involving three lecturers who taught Basic Speaking classes in the English Language Education Study Program of FKIP ULM. This research used observation and interview guidelines as the instruments. The data revealed that the lecturers in Basic Speaking classes used discussion, drilling, role play, game, dialogues, interview, talking stick, listening to audio recording, and question and answer as the techniques. Moreover, the techniques that the lecturers mostly used were discussion and role play. From the interview, the factors that underlie lecturers' choice in using certain techniques more often than other techniques were the topics, lesson objectives, students' needs, lecturer's interest, lecturer's experiences, and students' interest. Based on the result of this research, it is suggested that other researchers conduct further research in different levels of speaking classes to find out more information about teaching techniques in speaking classes. It is also recommended to conduct studies involving students to investigate their perceptions of the techniques teachers used in teaching English speaking skills.
\end{abstract}

Keywords: Lecturers, Teaching Techniques, Speaking, Basic Speaking Classes.

\section{INTRODUCTION}

English is spoken by many people worldwide and in so many areas of every daily life. In the era of globalization, people must master the English language from the beginning to be successful. Furthermore, English speaking ability is very important to communicate and participate in the wider world of work. Speaking is regarded as a crucial skill in order to express the speaker's intentions and effective oral communication results in getting success in various disciplines [1]. Because of this, lecturers and parents think that their students and children should master speaking abilities. Therefore, English teachers have to pay more attention to these skills in their EFL/ESL classrooms[1].

However, in Indonesian context, English is a foreign language which makes learning it become difficult. It is taught as a subject in schools but it is not extensively utilized for communication as ESL or English as a native language according to Widiati and Cahyono, 2006; Nunan, 2015 cited in Suban [2].
As a result, unlike ESL learners, who have numerous opportunities to utilize the language for communication, the EFL learners have limited opportunity to practice the language. This is a problematic task if we want to develop students' speaking skills. Hence, improving speaking skills by optimizing classroom time with practical activities may be a better option [2].

Speaking is a human's way to communicate. Through speaking, they can share ideas and knowledge. However, teachers may have certain difficulties in engaging students to speak in the classroom. Communication in L1, huge classes, and lack of time are some difficulties encountered in an EFL setting [3]. Other problems include inhibition, a lack of current information, and limited or uneven involvement [4].

One aspect that affects students' difficulty is the influence of their mother tongue $[4,6]$. Moreover, to resolve the difficulties in learning and to build Indonesian learners' confidence, the use of native language (L1) in English classrooms by some students and lecturers was considered necessary. In addition, the 
use of L1 in their English classes is beneficial to the teaching-learning process as long as it is not excessive and does not become a "habit" in the classroom. This is because students who are only taught in L1 have no ability to use English and have no possibility of mastering it [7].

Then, there are some cons when using L1 in the L2 classroom. First, overuse of L1 in teaching and learning process may develop a habit for both teachers and students that limits the use of target language. Second, when learners try to learn their target language, L1 with some distinctive features compared to L2 might lead to misunderstandings. Third, when the teachers employ L1 to teach students a foreign language, it may result in negative transfer to the target language [8].

To summarize, teachers' role in the EFL classroom is to provide learning opportunities for English-speaking students. Teachers' roles in EFL classrooms have a direct impact on students since they have the authority to manage and direct the lesson materials and learning procedures [9]. Moreover, the role of teachers will be critical because it will not always be easy to get students motivated [10]. Because of that fact, the lecturer has a responsibility to make their students speak English by using suitable speaking teaching techniques. If lecturers do not urge their students to talk in English, students will automatically use their first language to explain something to their classmates.

Considering the need to investigate how EFL teachers engage their students in speaking English, this research focuses on describing the techniques used and mostly used by the lecturer in English Language Education Study Program in teaching speaking. Especially, this study is aimed to explore the factors which underlie lecturers' choice in using a certain technique more often than other techniques to engage students to speak in Basic Speaking classes.

\section{LITERATURE REVIEW}

Speaking as a language skill has become a major topic in language classes $[11,12]$. Speaking is a useful aural/oral skill that makes systematic verbal utterances to convey information [13]. In addition, speaking refers to using words to express or exchange ideas [14]. Furthermore, the ability of students to speak in the target language is frequently used as a measurement for language learning success $[1,11,15]$.

Teachers employ teaching as a means of enabling students to learn. Teaching is defined as guiding and facilitating learning and allowing and assisting the student's learning [16]. Moreover, teaching speaking is a very significant part of second language learning. Teaching speaking in an EFL context different from those in ESL and English as a native language contexts,.
Bailey, in Suban [2] authorized five essential principles of teaching speaking in an EFL context. Those are :

- Be Aware of the Difference between Second Language and Foreign-Language Learning Contexts

- Give Students Practice Both Fluency and Accuracy

- Provide Opportunities for Students to Talk by Using Group Work or Pair Work and Limiting Teacher Talk

- Plan Speaking Tasks that Involve Negotiation of Meaning

- Design Classroom Activities that Involve Guidance and Practice in Both Transactional and Interactional Speaking

Therefore, language teachers must pay great attention to teaching speaking. Teachers should create a classroom environment where students have real-life communication, authentic activities, and meaningful oral language skills. By using communicative language teaching, students will have the opportunity to communicate in the target language [15]. Communicative Language Teaching (CLT) emphasizes the need to teach communicative competence as opposed to linguistic competence; thus, functions are stressed over forms. Students usually work with authentic materials in small groups on communicative activities [17].

Theoretical and practical knowledge should be integrated in order to successfully demonstrate language from a communicative perspective. A balance between theory and practice should be maintained in EFL instruction [3]. Communicative activities can motivate students and establish positive relationships between the teacher and the students, as well as among the students thereby establishing a supportive environment for language learning [18]. Communicative activities are significant to stimulate students' communication with one another in English class, and these activities should be range from easy to more complex depending on the students' level [19].

Teachers' Role in CLT classroom is as a facilitator whereas a learner is a participant. Through communicative activities they develop knowledge in a collaborative atmosphere in the classroom. The teacher facilitates the communication within the classroom as well as between students and the text and activities [20].

Teachers should select appropriate teaching techniques that encourage students to develop their speaking skills. The technique is a wide range of exercises, activities, or tasks utilized in the language classroom to achieve instructional goals [16]. Furthermore, selecting techniques in teaching speaking holds an important role in improving students' speaking skills. The teaching of speaking must open up vast opportunities for learners to practice [11]. Some 
principles in designing speaking techniques are as follow [16]:

- Focus on both fluency and accuracy, depending on your objective.

- Provide intrinsically motivating techniques.

- Encourage the use of authentic language in meaningful contexts.

- Provide appropriate feedback and correction.

- Capitalize on the natural link between speaking and listening.

- Give students opportunities to initiate oral communication.

- Encourage the development of speaking strategies.

In addition, techniques for teaching speaking contribute significantly to improving one's ability to communicate. Hence, the teaching of speaking must provide a variety of opportunities for students to develop their skills [11]. There are examples of techniques in the teaching of speaking: Information gap, Jigsaw exercises, Role-plays, Simulations, and Contact Assignment [13], discussions, role-play, simulations, storytelling, interviews, story completion, picture narrating, and picture describing [15], games, role play, and simulations, drama, projects, interviews, brainstorming, information gap, jigsaw activities, problem solving and decision making, and opinion exchange [16].

Besides selecting teaching techniques, some teachers have roles to get students to speak fluently, such as prompter, participant, and feedback provider [10]. Other teachers' roles are as controller, director, manager, resource, and facilitator [16], educators, instructors, mentor, trainers, adviser, demonstrator, corrector, inspirator, information provider, organizer, initiator, innovators, mediators, evaluators, motivator, manager, and facilitator according Wijaya, cited in Abida et al [21]. The EFL or ESL teachers' roles are not only limited to select effective techniques, but also to design and develop instructional materials which requires creativity and originality. Language learners can increase their language mastery by using well-designed educational resources. The choice of speaking instructional materials is influenced by the techniques used in teaching and learning process [11].

Basic Speaking course is offered in the second semester in the English Language Education Study Program of ULM. This course consists of 2 credits, and each student must pass this course to continue to Intermediate Speaking in the third semester. The main objective of this course is to develop students' speaking skills in using English expressions for everyday conversation namely expressing sympathy and condolences, expressing compliment, requesting, offering, complaining, asking and telling self and others' activities, project presentation, describing people, describing places and objects, asking and telling about health, apologizing and inviting, accepting, and rejecting the invitation.

\section{METHOD}

This research employed descriptive qualitative approach to provide a unique insight into student teachers' experiences. The instruments used were observation as the main instrument and interview as the secondary instrument.The research subjects were three lecturers who teach Basic Speaking classes in the second semester in the English Language Education Study Program at the University of Lambung Mangkurat, Banjarmasin, Indonesia.

The data was collected from the same source with different techniques. Observation sheet was used to collect the data followed by checklists on the techniques that were used by the lecturers in teaching speaking. Then, an interview was conducted to obtain more specific data about how the lecturers apply techniques in teaching speaking and why they use them.

To analyze the data, a qualitative approach was employed [22]. The data analysis were carried out in several steps as follows.

- Analyzing the data from observation by classifying them into sub themes and interpreting them.

- Analyzing the data from interviews by transcribing the interview records, classifying the data into sub themes, and interpreting them.

- Interpreting both data from observation and interview and drawing conclusions.

\section{RESULTS AND DISCUSSIONS}

\subsection{Results of the Observations}

\subsubsection{Techniques Lecturers' Used in Basic Speaking Classes at English Language Education Study Program}

The researcher conducted observation with three lecturers. Two lecturers had six meetings and one lecturer had three sessions. All the lecturers used different techniques in teaching speaking skills. In one meeting, the lecturers used some techniques. The explanations were divided into ten parts based on each technique found and used from three of the lecturers' classes; class Basic Speaking A1 by lecturer A, Basic Speaking A4 by lecturer B, and Basic Speaking A5 by lecturer $\mathrm{C}$. 
Table 1. The Techniques Found during the Observation

\begin{tabular}{|c|c|c|c|c|c|c|c|}
\hline \multirow{3}{*}{ No } & \multirow{3}{*}{ Lecturer } & \multicolumn{6}{|c|}{ Techniques used in Basic Speaking classes } \\
\hline & & \multicolumn{6}{|c|}{ Meeting } \\
\hline & & 1 & 2 & 3 & 4 & 5 & 6 \\
\hline \multirow[t]{5}{*}{1.} & Lecturer $\mathrm{A} /$ & 1 & 4 & 2 & 1 & 9 & 9 \\
\hline & Basic & 2 & 2 & 5 & 8 & 6 & 1 \\
\hline & Speaking & 3 & 1 & 7 & 5 & 1 & 4 \\
\hline & A1 & & 5 & 1 & & 4 & 3 \\
\hline & & & 6 & 3 & & & \\
\hline \multirow[t]{4}{*}{2.} & Lecturer B/ & 9 & 3 & 1 & & & \\
\hline & Basic & 1 & 1 & 3 & & & \\
\hline & Speaking & & 4 & & & & \\
\hline & A4 & & & & & & \\
\hline \multirow[t]{3}{*}{3.} & Lecturer $\mathrm{C} /$ & 10 & 1 & 10 & 10 & 1 & 9 \\
\hline & Basic & 9 & 3 & 2 & 2 & 3 & 10 \\
\hline & Speaking & 2 & & 1 & 7 & & 1 \\
\hline
\end{tabular}

\section{Note:}

$1=$ discussion

$2=$ drilling

$3=$ role play

$4=$ game

$5=$ dialogues

$6=$ interview

$7=$ talking stick

$8=$ listening audio recording

$9=$ question and answer

$10=$ song

Table 1 shows some techniques used by the lecturers in teaching speaking in Basic Speaking classes. There are:

\subsubsection{Discussions}

Lecturer A always used this technique in every meeting. The first observation was held on February 15, 2019. The topic of the lesson was expressing sympathy and condolences. In the next meeting, the topic in this second meeting was requesting and was observed on February 22, 2019. On March 8, 2019, lecturer A used this technique in the third meeting. The topic of the lesson was offering. The topic of the next meeting in lecturer A class was expressing complaints. The fourth observation was conducted on March 15, 2019. The fifth meeting was conducted on March 22, 2019. The topics were asking and telling self and others' activities. Finally, the last meeting observed in this class was on April 26, 2019. The topic was describing people.

Meanwhile, lecturer B applied this technique thrice in all her meetings. The topic for the first meeting in lecturer B's class was expressing sympathy and condolences. This research was conducted on February 14, 2019. The topic of the next meeting was expressing compliments. The observation in this second meeting was on February 21, 2019. Finally, the topic for the third observation on February 28, 2019, in this class was requesting.

Lastly, lecturer $\mathrm{C}$ used this technique in the second, third, fifth, and last meetings. Moreover, lecturer C's second meeting expressed sympathy and condolences and was observed on February 21, 2019. The third time observed was on February 28, 2019. The topic was expressing compliments. The fifth meeting was conducted on March 21, 2019. The topic was expressing complaints. The last meeting was on April 26, 2019. The topic was describing people.

\subsubsection{Drilling}

Lecturer A implemented this technique, but Lecturer B did not apply it in the first, second, and third meetings. The first observation was held on February 15, 2019. The topic of the lesson was expressing sympathy and condolences. The topic in this second meeting was requesting and was observed by the researcher on February 22, 2019. March 8, 2019, was the third time the researcher observed this class. The topic of the lesson was offering.

Moreover, lecturer $\mathrm{C}$ used this technique three times in the first, third, and fourth meetings. The first meeting was on February 14, 2019. The topic of this meeting was expressing sympathy and condolences. The third time the researcher observed this class was on February 28, 2019. The topic was expressing compliments. Finally, on March 14, 2019, the researcher continued to observe the following meeting. The topic of the fourth meeting was offering.

\subsubsection{Role Play}

Mostly all the lecturers used this technique when teaching speaking in class Basic Speaking. Lecturer A used this technique in three meetings: first, third, and last meeting. The first observation that the researcher held in this class was on February 15, 2019. The topic of 
the lesson was expressing sympathy and condolences. March 8, 2019, was the third time the researcher did; the lesson's topic was offering. The sixth meeting was on April 26, 2019. The topic was describing people.

Lecturer B applied this technique in the second and third meetings. The topic of this meeting was expressing compliments. The observation in the second meeting was on February 21, 2019. The research was held for the third time. The topic was requesting.

Meanwhile, it had been used two times by lecturer $\mathrm{C}$ in the second and fifth meetings. In the second meeting in Basic Speaking A5, the topic lecturer $\mathrm{C}$ had expressed sympathy and condolences and was observed on February 21, 2019. The fifth meeting was conducted on March 21, 2019. Again, the topic was expressing complaints.

\subsubsection{Game}

Lecturer $\mathrm{C}$ was the only one who did not use this technique. On the other hand, lecturer A usually used this technique, and she applied it three times in the second, fifth, and sixth meetings. The topic in lecturer A second meeting was requesting and was observed on February 22, 2019. The fifth meeting was conducted on March 22, 2019. The topic was asking and telling self and others' activities. Finally, the sixth meeting was on April 26, 2019. The topic was describing people.

In addition, lecturer B applied this technique once in the second meeting. The topic of the second meeting was expressing compliments. The observation was conducted on February 21, 2019.

\subsubsection{Dialogues}

Both lecturer B and lecturer C did not use this technique. Only lecturer A applied this technique in the second, third, and fourth meetings. The topic in the second meeting was requesting and was observed on February 22, 2019. The researcher researched for the third time on March 8, 2019. The topic of the lesson was offering. The topic of the following meeting was expressing complaints. This observation was conducted on March 15, 2019.

\subsubsection{Interview}

Lecturer B and lecturer $\mathrm{C}$ did not use this technique. Unlike other lecturers, lecturer A was the only one who applied this technique. It was used by her two times in the second and fifth meetings. The topic in the second meeting was requesting and was observed on February 22, 2019. The fifth meeting was conducted on March
22, 2019. The topic was asking and telling self and others' activities.

\subsubsection{Talking Stick}

This technique is applied by two lecturers, lecturer A and lecturer C. Both of them used it once in their Basic Speaking class. Lecturer A applied this technique in the third meeting on March 8, 2019. The topic of the lesson was offering. Meanwhile, lecturer $\mathrm{C}$ used it in the fourth meeting. The researcher did observation the teaching process with the topic of offering on March 14, 2019.

\subsubsection{Listening Audio Recording}

Lecturer A in class Basic Speaking A1 was the only one to use this technique. She applied it in the fourth meeting. The topic of this meeting was expressing complaints. This observation was conducted on March 15,2019 .

\subsubsection{Question and Answer}

All the lecturers used this technique, and lecturer A used this technique once in the last meeting. In the sixth meeting, the researcher observed this class on April 26, 2019. The topic was describing people.

Lecturer B in class Basic Speaking A4 used this technique once in her first meeting. This first meeting was conducted on February 14, 2019. The topic was expressing sympathy and condolences.

Moreover, lecturer $\mathrm{C}$ in class Basic Speaking A5 applied this technique twice in the first and the last meeting. The first meeting was on February 14, 2019. The topic of this meeting was expressing sympathy and condolences. The last observation meeting was on April 26,2019 . The topic was describing people.

\subsubsection{Song}

The difference with this technique, only lecturer $\mathrm{C}$ in class Basic Speaking A5 used this technique. She applied it four times in the first, third, fourth, and sixth meetings. The first time the research was held was on February 14, 2019. The topics discussed were expressing sympathy and condolences. The third time was on February 28, 2019, with the topic of expressing compliments. After that, the researcher did observation for the fourth time on March 14, 2019, with the topic of offering. Finally, the sixth observation meeting was on April 26, 2019. The topic was describing people.

\subsubsection{The Most Techniques Used by Lecturers in Basic Speaking Classes at English Language Education Study Program}


Table2. Teaching Techniques Tabulation Result

\begin{tabular}{lccc}
\multicolumn{1}{c}{ Techniques } & Lecturer A & Lecturer B & Lecturer C \\
\hline Discussion & 6 & 3 & 4 \\
\hline Drilling & 3 & 0 & 3 \\
\hline Role Play & 3 & 2 & 2 \\
\hline Game & 3 & 1 & 0 \\
\hline Dialogues & 3 & 0 & 0 \\
\hline Interview & 2 & 0 & 0 \\
\hline Talking stick & 1 & 0 & 1 \\
\hline Listening audio recording & 8 & 0 & 0 \\
\hline Question and answer & 2 & 1 & 2 \\
\hline Song & 0 & 0 & 3 \\
\hline
\end{tabular}

As displayed in Table 2, some techniques are mostly used by the three lecturers in teaching speaking in Basic Speaking classes. The techniques are discussion and Role Play.

\subsection{Results of Interview}

\subsubsection{Factors Underlie Lecturers' Choice in Using One Technique than others}

The followings are the conclusion from the interview with three lecturers.

\subsubsection{Speaking in Basic Speaking Course}

Speaking learning in Basic Speaking class is a course that the second-semester students must take, and they are taught fixed expressions in pairs or groups, which they could use in the next level of speaking course.

\subsubsection{Purpose of Teaching Speaking in Basic Speaking Course}

The Basic Speaking class is meant to help students improve their speaking skills and make them familiar with expressing conversation in daily life rather than academic context and idiom before continuing to the next level of speaking class.

\subsubsection{The Use of Teaching Technique in Basic Speaking Course}

The use of the technique in Basic Speaking classes is to guide students, initiate students' activeness, and motivate students by using cooperative learning.

\subsubsection{Special Teaching Technique Lecturers Used in Teaching Basic Speaking Course}

The special techniques that the lecturers used in Basic Speaking class are cooperative learning, such as role-play, presentation, and singing.

\subsubsection{The Source of Lecturers Teaching Technique in Teaching BasicSpeakingCourse}

The teaching techniques that lecturers use in teaching Basic Speaking are books, videos from previous Basic Speaking classes, lecturers' experiences in other courses, and lecturers' experiences in IELTS class.

\subsubsection{The Most Technique Lecturers Used in Teaching Basic Speaking Course}

From the interview, the most technique the lecturers used in Basic Speaking was role play.

\subsubsection{Factors Underlie Lecturers' Choice in Using One Technique than others}

The factors that underlie lecturers' choice in class Basic Speaking are topic, lesson objective, lecturer's need, lecturer's view, lecturer's experience, and students' interest.

\subsubsection{The Difference of Use Teaching Technique in Basic Speaking Course}

There was no difference in the use of teaching techniques in the three Basic Speaking classes.

\subsubsection{The Difficulties when Using Teaching Techniques in Basic Speaking}

The obstacles lecturers found in teaching speaking in Basic Speaking were the students' personalities, number of students, handout, and limited vocabulary.

\subsubsection{The Purpose of Lesson by Using Teaching Technique}

The teaching speaking technique used in two Basic Speaking classes still has not yet achieved the purpose of the lesson, because the lecturers needed an evaluation later in the final test. Some students did not speak English fluently and some students were not using full English until in the middle of semester when this research was done. However, the technique used in one 
Basic Speaking class has achieved $85 \%$ of the lesson's purpose. It was because the students could speak English well using the expressions that the lecturers had taught.

\subsection{Discussion}

From the research findings, the lecturers used some techniques in Basic Speaking classes in the English Language Education Study Program of FKIP ULM. There were ten techniques that the lecturers used, which consisted of drilling, role play, game, dialogues, interview, talking stick, discussion, listening to audio recording, question, and answer, and listening to songs. However, the mostly used techniques in Basic Speaking classes were discussion and role play. The lecturers mentioned that they used these techniques to guide students, initiate students' activeness, and motivate students by using cooperative learning. This is in line with the theory that free discussion and role-play are preferable for improving students' oral production, according to Hedge, cited in Al-Garni and Almuhammadi[19].

Speaking as a social activity is accomplished as well, if pair and group work goes well, students will have more opportunity to negotiate meaning, engage in meaningful conversation, and learn to take turns [2]. Hence, the purpose of speaking in the Basic Speaking course is to enhance and make the students fluent in speaking can be achieved by using discussions and roleplay which can promote students to practice speaking in English.

This study also tried to determine the factors that underlie the lecturers' choice to use certain techniques more often than other techniques in Basic Speaking class. The interview results show that the students were trained to make and perform dialog and conversations by using role-play with their friends in pairs or groups. The lecturers provided the reason for using role-play is that it is appropriate to give students the chance to speak in English. In line with this, studies show that role play successfully evaluated and encouraged college students to collaborate and engage their communication in groups and pairs and enhance their speaking skills in the target language $[18,23]$.

Furthermore, other reasons affecting the lecturers' choice were the lecturer's need, the lecturer's view, and the lecturer's experience. The lecturer's need is her consideration based on the urgency, the requirement for the technique to be used, and when and where it is required. For instance, the lecturers used video before role-playing when a good model of conversation is needed. In that way, students can act out a real issue in the classroom after they watch the model role play. This technique brings a lot of fun and thus motivating; allows hesitant students to be more forthright in their opinions and behavior, and allows students to use a much wider range of language than some more task-centered activities might allow [23]. The lecturer also used games that involved students' speaking ability when the classroom atmosphere required. In a nutshell, the techniques implemented depend on the urgency and for what purpose.

In addition, the lecturer's view is a factor that influences the lecturers' choice of using certain techniques more often than other techniques.This is based on the lecturer's belief that a good teacher should put herself as a student to understand her student's feelings and attitude toward learning. Therefore, if the teacher finds that a technique used frequently is not interesting anymore, she can conclude that the students were bored too. The lecturer then modified the topic by changing the sequences of the topics and used other techniques than role play.

Moreover, those three lecturers have different experiences. From those experiences, they can decide what kind of teaching techniques they used to achieve the goals of the Basic Speaking class.

The last factor was students' interest. When the techniques used by the lecturer make students more interested and more active in the speaking class, it means that the goal of the speaking class has been achieved. This follows the role of the lecturer as a motivator and facilitator. As explained by Wijaya cited in Abida et al. [21], teachers are educators, instructors, mentor, trainers, adviser, demonstrator, corrector, inspirator, information provider, organizer, initiator, innovators, mediators, evaluators, motivator, manager, and facilitator.

As a motivator, teachers should be able to urge students to be passionate and active in learning. To increase students' motivation, teachers can analyze the motives that underlie students' lazy learning and decreased performance in school. The lecturers motivated the students by paying attention to their needs of students [21]. As revealed in the study, the lecturer used varied techniques and applied games that involved students' speaking ability when the students seemed bored with the lesson.

Moreover, the teacher's role as a facilitator is also important. The meaning of the facilitator is to give convenience. Suban [2] stated that in CLT the role of teacher as a facilitator and student as a participant. Teachers as facilitators should work on meaningful learning resources and can support the achievement of goals and the teaching and learning process, whether in the form of resource persons, textbooks, magazines, or newspapers [21]. 


\section{CONCLUSION AND SUGGESTION}

\subsection{Conclusion}

In Basic Speaking classes, the lecturers used discussion, drilling, role play, game, dialogues, interview, talking stick, listening to audio recording, question and answer, and listening to song. In addition, the techniques that are mostly used are discussion and role play. Furthermore, the factors that underlie lecturers' choice in using certain techniques more often than other techniques in Basic Speaking classes are the topics, lesson objectives, lecturer's need, lecturer's interest, lecturer's experiences, and students' interest.

\subsection{Suggestion}

The findings imply that further research is needed to investigate the teaching of English speaking at different levels to reveal more comprehensive information about teaching techniques in EFL speaking classes. It is also recommended to conduct studies to investigate students' perceptions about teachers' techniques in teaching English speaking skills.

\section{AUTHORS' CONTRIBUTIONS}

Author 1 contributed to the design of the study and data analysis. Author 2 participated in enriching the literature and improving the research design. Meanwhile, Author 3 participated in the data analysis and writing format.

\section{ACKNOWLEDGMENTS}

The authors acknowledge and are very grateful to the subjects of the research, the lecturers of Basic Speaking courses, who were willing to be observed during their teaching and interviewed about the techniques in teaching speaking skills.

\section{REFERENCES}

[1] P. S. Rao, Novel Approaches for Teaching Speaking Skills in Efl / Esl Classrooms: a Comprehensive Study Research Article Novel Approaches for Teaching Speaking Skills in Efl / Esl Classrooms : a Comprehensive Study, Res. J. English Lang. Lit. A Peer Rev. Int. J., vol. 7, 2019, pp. 489-498, DOI: 10.33329/rjelal.7119.489.

[2] T. S.-L. J. of Language and 2021, "Teaching Speaking: Activities to Promote Speaking Skills in EFL Classrooms," journal.unwira.ac.id, Accessed: Sep. 19, 2021. [Online]. Available: https://www.journal.unwira.ac.id/index.php/LE CTIO/article/view/888. investigation of the difficulties faced by EFL undergraduates in speaking skills, in: Proceedings of English Lang. Teach., vol.7, 2013, pp. 19-27, DOI: 10.5539/elt.v7n1p19.

[4] N. H. Tuan, T. N. Mai, Factors affecting students' speaking performance at Le Thanh Hien high school, in: Proceedings of Asian J. Educ. Research, vol.3, 2015, vol. 3, pp. 8-23.

[5] L. M. Leong, S. M. Ahmadi, An Analysis of Factors Influencing Learners' English Speaking Skill, in: Proceedings of Int. J. Res. English Educ., vol.2, 2017, pp. 34-41. DOI: 10.18869/acadpub.ijree.2.1.34.

[6] F. Al-Esaifer, in: Proceedings of Journal of English, and peaking challenges that encounter 2nd and 3rd year EFL university students, scholar.archive.org, 2018, pp. 49-56. DOI: 10.24127/pj.v7i1.

[7] E. Haryanto, U. Sulistiyo, M. Khairani, and R. Wulan, in: Indonesian or English? EFL Student Teachers' Preference and Perception on the Language Use in the Classroom, in: Proceedings of IJEE, vol. 3, 2016, pp. 46-59, DOI: 10.15408/ijee.v3i1.3941.

[8] C. G. Voicu, Overusing mother tongue in English language teaching, in: Proceedings of Int. J. Commun. Res., vol. 2, 2012, pp. 212-218.

[9] C. T. Paul, T. Hui-Ling, Implicit and Explicit Teaching of English Speaking in the EFL Classroom, in: Proceedings of Int. J. Humanit. Soc. Sci., vol. 4, 2014, pp. 38-46.

[10] J. Harmer, The Practice of English Language Teaching (4th ed). England: Pearson-Longman, 2007.

[11] K. Manurung, Improving the Speaking Skill Using Reading Contextual Internet-based Instructional Materials in an EFL Class in Indonesia, in: Proceeding of Soc. Behav. Sci., vol. 176, 2015, pp. 44-51. DOI: 10.1016/j.sbspro.2015.01.442.

[12] Y. K. Aeni, the Use of Think Pair Share Technique in Teaching Speaking, in: Proceedings of Proj. (Professional J. English Educ., vol. 3, 2020, pp. 570-576. DOI: 10.22460/project.v3i5.p570-576.

[13] D. Nunan, Practical English Language Teaching. New York: McGraw- Hill, 2003.

[14] C. T. Mart, Developing Speaking Skills through Reading, in: Proceedings of Int. J. English Linguist. vol. 2, 2012. DOI: 10.5539/ijel.v2n6p91.

[15] J. Anora, Modern approaches in teaching speaking, Jspi, 2020. 
[16] H. D. Brown, Teaching by Principles: An Interactive Approach to Language Pedagogy, (4th ed), New York, Pearson Education, 2007.

[17] C. Intarapanich, Teaching Methods, Approaches and Strategies Found in EFL Classrooms: A Case Study in Lao PDR, in: Proceding of Soc. Behav. Sci., vol. 88, 2013, pp. 306-311, DOI: 10.1016/j.sbspro.2013.08.510.

[18] T. Oradee, Developing Speaking Skills Using Three Communicative Activities (Discussion, Problem-Solving, andRole-Playing), in: Proceedings of Int. J. Soc. Sci. Humanit., vol. 2, 2012, pp. 533-535, 2013. DOI: 10.7763/ijssh.2012.v2.164.

[19] S. A. AL-Garni, A. H. Almuhammadi, The Effect of Using Communicative Language Teaching Activities on EFL Students' Speaking Skills at the University of Jeddah, in; Proceedings of English Lang. Teach., vol. 12, 2019, pp. 72. DOI: 10.5539/elt.v12n6p72.

[20] A. A. Al Asmari, Communicative language teaching in efl university context: Challenges for teachers, in: Proceedings of J. Lang. Teach. Res., vol. 7, 2015, pp. 976-984. DOI: 10.17507/j1tr.0605.09.

[21] A. A. F. Putri, H. Andriningrum, S. Khusnul Rofiah, I. Gunawan, in: Proceedings of Teacher Function in Class: A Literature Review, vol. 382, 2019, pp. 5-9. DOI: 10.2991/icet19.2019.2.

[22] H. H. Fraenkel, J.R. Wallen, N.E. Hyun, How to Evaluate Research in Education (8th ed.), New York, McGraw- Hill, 2012.

[23] D. M. Krebt, The effectiveness of role play techniques in teaching speaking for efl college students, in: J. Lang. Teach. Res., vol. 8, 2017. DOI: pp. 863-870. DOI: 10.17507/jltr.0805.04. 